\title{
SINGLE-CENTER RETROSPECTIVE SERIES OF INTRACRANIAL ANEURYSMS TREATED WITH THE BARRICADE COIL SYSTEM: IMMEDIATE AND SIX-MONTH RESULTS
}

\author{
Kārlis Kupčs ${ }^{1,3}$, Aigars Lācis ${ }^{1,3, \#}$, Zane Saleniece ${ }^{1,2}$, and Helmuts Kidikas ${ }^{1}$ \\ ${ }^{1}$ Pauls Stradiṇš Clinical University Hospital, 13 Pilsoṇu Str., Rīga, LV-1002, LATVIA \\ 2 University of Latvia, Raiṇa bulvāris 19, Rīga, LV-1586, LATVIA \\ ${ }^{3}$ Rīga Stradinš University, 16 Dzirciema Str., Rĩga, LV-1007, LATVIA \\ \# Corresponding author, aigars.lacis@yahoo.com
}

Communicated by Pēteris Stradiṇ̌

\begin{abstract}
Intracranial aneurysms (IAs) are most commonly found at the branch points of large arteries that form the circle of Willis. The prevalence of IAs in the adult population is 1-5\%. IAs rupture is associated with subarachnoid haemorrhage (SAH) in 6-8 cases per 100000 population, causing mortality in 40-50\%. Aneurysm treatment is used to prevent rupture or rebleeding (for ruptured IAs). Randomised trials demonstrated the superiority of endovascular treatment (EVT) of ruptured aneurysms with coil systems over surgery. The objective of the study was to evaluate the effectiveness of the Barricade coil system in the treatment of intracranial aneurysms. Detachable platinum coils, since their introduction 25 years ago, have become the first choice EVT method for ruptured and unruptured IAs and have shown acceptable mortality ( 2\%). The retrospective study of intracranial aneurysms treated with the Barricade coil system at Pauls Stradiňs Clinical University Hospital (Riga, Latvia) conducted in a 20-month period included 95 patients and 97 IAs. Thirty-one (32.6\%) males and $64(67.4 \%)$ females with median age $56 \pm 15$ years underwent endovascular treatment. The minority, 22 (23.16\%) patients, were asymptomatic, while 73 (76.84\%) patients had neurological symptoms directly associated with aneurysm progression and SAH development. Preoperatively, 52 (53.6\%) aneurysms were ruptured, causing SAH, and 24 (25.26\%) patients with unruptured IAs had neurological symptoms. Sixty-four (66.0\%) IAs were treated using coils without neurovascular stent implantation or balloon assistance, $22(22.7 \%)$ with coils and stent implantation, and 11(11.3\%) aneurysms were embolised with balloon-assisted coiling. The immediate anatomical result of endovascular treatment of IAs and technical success of aneurysm coiling was evaluated using the simplified Raymond scale. In the majority of cases, complete occlusion of the aneurysm was achieved while residual neck of the aneurysm or aneurysm remnant was uncommon. Immediate clinical results were evaluated using the modified Rankin scale (mRs). The majority of patients had favourable immediate clinical outcome (mRs $0-2)$, but four (4.21\%) patients died in 1-6 days after the procedure as a consequence of SAH. In $72(75.79 \%)$, patients no new neurological pathological symptoms developed 2-3 days after endovascular procedure and they were discharged from the hospital. Intraprocedural complications occurred in $4(4.21 \%)$ cases. Technical issues occurred in two (2.1\%) patients. In $19(20 \%)$ patients, neurological symptoms remained even after the procedure, six (6.32\%) patients had clinical worsening, and we had one case of procedural related mortality. Six-month follow-up evaluation was performed for $58(61.0 \%)$ patients $(59 \mathrm{IAs})$. In the majority of cases, complete occlusion of the aneurysm and favourable clinical outcome (mRs $0-2)$ was observed. Our experience showed that the treatment of ruptured and unruptured intracranial aneurysms with the Barricade coil system is feasible, effective, clinically safe and has a low risk of intraprocedural complications.
\end{abstract}

Key words: intracranial aneurysms, Barricade coil system, neuroendovascular treatments, endovascular treatment. 


\section{INTRODUCTION}

Intracranial aneurysms (IAs) are most commonly found at the branch points of large arteries that form the circle of Willis at the base of the brain. In $85-95 \%$ of patients IAs are found in the anterior circulation. Aneurysms in the posterior circulation are less frequent but they are more complicated to treat (Anonymous, 2006).

The prevalence of IA in the adult population is $1-5 \%$ (Pierot et al., 2008).

Most IAs are small and asymptomatic. Large aneurysms may have a mass effect, leading to compression on the brain and cranial nerves and neurological deficits.

IA rupture is associated with subarachnoid haemorrhage (SAH). Aneurysmal SAH develops in 6-8 cases per 100000 population (Grochowski et al., 2018). IA rupture is associated with mortality rate up to $40-50 \%$ and severe morbidity of 10-20\% (Raaymakers et al., 1998).

The overall risk of rupture is higher for women, cigarette smokers and cocaine users, and in aneurysms that are symptomatic or larger than $10 \mathrm{~mm}$. The International Study of Unruptured Intracranial Aneurysms (ISUIA) proved increased risk of rupture for posterior circulation IAs (Wiebers et al., 2003). There is a risk of repeat haemorrhage with increased mortality for ruptured untreated aneurysms.

Aneurysm treatment is undertaken to prevent rupture (for unruptured aneurysms) or rebleeding (for ruptured aneurysms). The randomised International Subarachnoid Aneurysm Trial (ISAT) demonstrated the superiority of endovascular treatment (EVT) of ruptured aneurysms with coil systems over surgery (Molyneux et al., 2002). Aneurysm coiling is a minimally invasive alternative to open surgery and is associated with excellent functional outcomes and satisfying anatomical results.

Since their introduction 25 years ago, detachable platinum coils have become the first choice EVT method for ruptured and unruptured IAs (Zidan et al., 2016).

The development of endovascular coils with a controlled detachable system was the first significant step for widespread use of EVT (Pierot and Wakhloo, 2013).

Endovascular coils vary on the basis of factors such as size, metal composition, stiffness, and detachment mechanism. It is important to evaluate the performance of a new coil in terms of safety and efficacy.

Balloon-assisted coiling was originally developed for the treatment of wide-neck aneurysms, but it was demonstrated that, in the setting of intraoperative rupture, balloon assistance was associated with a higher chance of unchanged or improved clinical outcome compared with standard coil embolisation (Santillan et al., 2012).

Stent-assisted coiling was presented more than ten years ago to overcome some limitations of standard coiling and to help treat complex aneurysms, including wide-neck aneurysms, large and giant aneurysms, and fusiform aneurysms (Wakhloo et al., 2008). Stenting was considered to prevent aneurysm recanalisation.

The safety of IA treatment with bare platinum coils has been widely described in the literature (Bennaisa et al., 2015). Initial large studies described acceptable mortality $(\sim 2 \%)$ and morbidity (4-9\%), related primarily to thromboembolic complications and intraoperative rupture (Cognard et al., 1998).

Barricade coils (Blockade Medical, Irvine, California, USA) are bare platinum coils introduced in European market in 2012 (Guerreiro-Simoes et al., 2019). The Barricade Coil System has extremely high deliverability due to a tapered stainless steel wire design. The proximal diameter of 0.012 " allows good pushability and a very soft distal detachment zone guarantees minimal coil kickback (measures 0.002" distally). The biggest benefit lies in the fact that Barricade Coils have a unique electrolytic detachment zone, which is very short and allows for very reliable $1^{\text {st }}$ cycle detachments. The Barricade Filling Coil is a helical, which provides efficient packing through variable softness profile as the coils get smaller they get softer. Barricade is a coil line available in framing, filling and finishing configurations. The framing coils provide an even loop distribution and stable basket for a wide assortment of IA shapes.

\section{PATIENTS AND METHODS}

The retrospective study of intracranial aneurysms treated with the Barricade coil system at Pauls Stradinš Clinical University Hospital (Rīga, Latvia) was conducted in a 20month period since January 2016 to August 2017. The study included 95 patients and 97 IAs.

Thirty-one (32.6\%) males and $64(67.4 \%)$ females with median age $56 \pm 15$ years (range 15 to 85 years) underwent endovascular treatment. The minority - 22 (23.16\%) patients, were asymptomatic, while $73(76.84 \%)$ patients had neurological symptoms directly associated with aneurysm progression and subarachnoid haemorrhage (SAH) development — severe headache, dizziness and nausea.

Preoperatively, 52 (53.6\%) aneurysms were ruptured, causing SAH, and 24 (25.26\%) patients with unruptured IAs had neurological symptoms.

The most frequent locations of intracranial aneurysms were anterior cerebral artery (ACA), anterior communicating artery (ACom) and intracranial part of internal carotid artery (icICA) (Table 1).

In the pre-operative characterisation of intracranial aneurysm, the following indicators were taken into account there was or there was no aneurysm rupture, aneurysm size, and aneurysm neck size. 
Table 1. Characteristics of intracranial aneurysms in studied patients

\begin{tabular}{|l|c|}
\hline \multicolumn{2}{|c|}{ Aneurysm location } \\
\hline ACA/ACom & $30(30.9 \%)$ \\
\hline icICA & $28(28.9 \%)$ \\
\hline MCA & $17(17.5 \%)$ \\
\hline PCom & $6(6.2 \%)$ \\
\hline BA & $6(6.2 \%)$ \\
\hline PCA & $4(4.1 \%)$ \\
\hline PICA & $4(4.1 \%)$ \\
\hline PA & $1(1.0 \%)$ \\
\hline \multicolumn{2}{|c|}{ Diameters (mean \pm SD) } \\
\hline Longer axis & $2-20 \mathrm{~mm}$ (average $5.9 \pm 2.9 \mathrm{~mm})$ \\
\hline Shortest axis & $2-9 \mathrm{~mm}$ (average $4.4 \pm 1.7 \mathrm{~mm})$ \\
\hline Neck of the aneurysm & $2-6 \mathrm{~mm}$ (average $2.9 \pm 0.9 \mathrm{~mm})$ \\
\hline
\end{tabular}

ACA, anterior cerebral artery; ACom, anterior communicating artery; icICA, intracranial part of internal carotid artery; MCA, middle cerebral artery; PCom, posterior communicating artery; BA, basilar artery; PCA, posterior cerebral artery; PICA, posterior inferior cerebellar artery; PA, pericallosal artery.

Sixty-four $(66.0 \%)$ IAs were treated using coils without neurovascular stent implantation or balloon assistance, 22 $(22.7 \%)$ with coils and stent implantation, and 11(11.3\%) aneurysms were embolised with balloon-assisted coiling.

Endovascular treatment of IAs with the Barricade coil system was performed by a team of three neurointerventionists on a biplane flat-panel angiography machine (Axiom Artis dBA, Siemens, Erlangen, Germany).

All procedures were performed using common femoral artery access with $6 \mathrm{~F}$ introducer sheath and $6 \mathrm{~F}$ guiding catheter. The Barricade coils were delivered by using a 1,7 F microcatheter and 0.014 inch guidewire.

All procedures were done under general anaesthesia with endotracheal intubation.

Baseline ACT (Activated Clotting Time) was detected prior to the procedure. At the beginning of the manipulation, 5000 IU Heparin was administered intravenously. The ACT was determined 15 minutes later. In standard situations, it should rise 2-3 times above baseline. If the ACT was extended less than two times above baseline, an additional heparin 1000 IU was administered intravenously. The ACT was determined throughout the procedure, once every hour. The fractionated heparin was administered at therapeutic doses for the first 24 hours following the procedure.

If elective endovascular treatment with the Barricade coil system for unruptured intracranial aneurysm was planned without stent implantation, $75 \mathrm{mg}$ oral Aspirin was administered one day prior to the procedure, and continued one month after the procedure.

If elective endovascular treatment with the Barricade coil system for unruptured intracranial aneurysm was planned and stent implantation was also intended, $75 \mathrm{mg}$ oral Clopidogrel was administered one week before the procedure and oral Aspirin $75 \mathrm{mg}$ was added one day before the procedure.
Following the procedure, oral Clopidogrel $75 \mathrm{mg}$ administration was continued for a month and oral Aspirin $75 \mathrm{mg}$ for 6 months. Endovascular treatment methods for ruptured intracranial aneurysms did not differ from those in patients undergoing elective surgery. The only difference was the ability to prepare patients prior to the scheduled surgery with timely antiaggregating.

Ethical approval to report these data was obtained from Pauls Stradins Clinical University Hospital Ethics Commitee.

\section{RESULTS}

The immediate anatomical result of endovascular treatment of IAs and technical success of aneurysm coiling was evaluated using the simplified Raymond scale (Mascitelli et al., 2015): complete occlusion of the aneurysm corresponded to grade 1 , aneurysm neck remnant to grade 2, and aneurysm remnant to grade 3 .

In the majority of cases, complete occlusion of the aneurysm was achieved while residual neck of the aneurysm or aneurysm remnant was uncommon (Table 2).

The immediate clinical results of endovascular treatment of intracranial aneurysms with the Barricade coil system were evaluated using the modified Rankin scale (Broderick et al., 2017). This scale is used to measure the degree of disability in patients who have had a stroke or other causes of neurological disability. The modified Rankin scale ( $\mathrm{mRs}$ ) is from 0 (perfect health without symptoms) to 6 (death). Morbidity is defined as $\mathrm{mRs}$ of 2 to 5 .

The majority of patients had favourable immediate clinical outcome (mRs 0-2) after the coiling procedure, but four $(4.21 \%)$ patients died within 1-6 days after the procedure, all of them presenting with a ruptured aneurysm and death as a consequence of SAH. An assessment of the neurological condition with the Rankin scale prior to surgery was not performed in patients who were unconscious. Consequently, the assessment of neurological progress in the overall view according to the Rankin scale of all patients involved in the study would not be objective (Table 3 ).

Table 2. Comparative analysis of anatomical immediate post-procedural results in patients with ruptured and unruptured intracranial aneurysms using the simplified Raymond scale

\begin{tabular}{|l|c|c|c|}
\hline \multirow{2}{*}{} & \multicolumn{2}{|c|}{ Status of aneurysm } & \multirow{2}{*}{ Total } \\
\cline { 2 - 3 } & ruptured & unruptured & \\
\cline { 2 - 3 } & $52(53.60 \%)$ & $45(46.40 \%)$ & $97(100.00 \%)$ \\
\hline \multicolumn{2}{|c|}{ Immediate anatomical results } & \multicolumn{2}{|c|}{$88(90.72 \%)$} \\
\hline Complete occlusion & $47(48.45 \%)$ & $41(42.27 \%)$ & $8(8.25 \%)$ \\
\hline $\begin{array}{l}\text { Residual neck of } \\
\text { the aneurysm }\end{array}$ & $5(5.15 \%)$ & $3(3.10 \%)$ & $1(1.03 \%)$ \\
\hline Residual aneurysm & $0(0 \%)$ & $1(1.03 \%)$ & \\
\hline
\end{tabular}

Residual neck of the aneurysm — resistance of any portion of the original defect of the arterial wall but without opacification of the aneurysm sac. Residual aneurism - any opacification of the aneurysm sac 
Table 3. Comparative analysis of clinical immediate post-procedural results in patients with and without subarachnoid haemorrhage

\begin{tabular}{|c|c|c|c|}
\hline \multirow{2}{*}{} & \multicolumn{2}{|c|}{ Subarachnoid haemorrhage } & \multirow{2}{*}{ Total } \\
\cline { 2 - 3 } & SAH+ & SAH- & \\
\cline { 2 - 3 } & $50(52.63 \%)$ & $45(47.37 \%)$ & \multirow{2}{*}{$95(100.00 \%)$} \\
\hline \multicolumn{2}{|c|}{ Immediate clinical results } & \\
\hline mRs 0-2 & $36(37.89 \%)$ & $45(47.37 \%)$ & $81(85.26 \%)$ \\
\hline mRs 3-4 & $7(7.37 \%)$ & $0(0 \%)$ & $7(7.37 \%)$ \\
\hline mRs 5-6 & $7(7.37 \%)$ & $0(0 \%)$ & $7(7.37 \%)$ \\
\hline
\end{tabular}

$\mathrm{SAH}+$ patients with subarachnoid haemorrhage detected prior endovascular treatment.

SAH- patients without subarachnoid haemorrhage detected prior endovascular treatment. Modified Rankin scale (mRs): 0 - no symptoms; 1 - no significant disability; 2 - slight disability; 3 - moderate disability; 4 - moderate to severe disability; 5 - severe disability; 6 - dead.
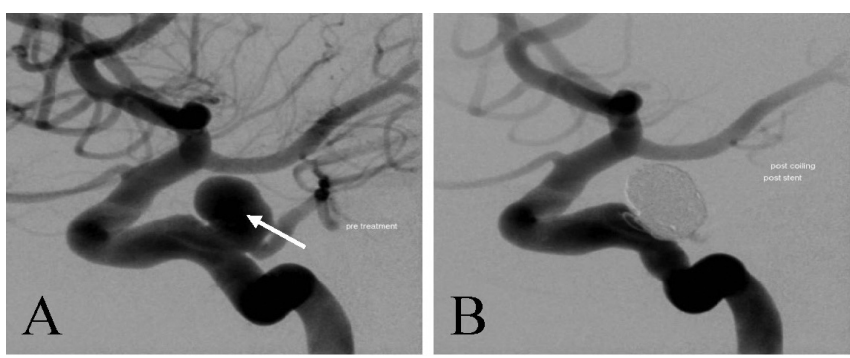

Fig. 1. Digital subtraction angiography of successful treatment of the aneurysm of the internal carotid artery treated with Barricade coil system with stent-assisted coiling.

A, preprocedural angiography of the unruptured aneurysm (arrow). B, postprocedural angiography of complete occlusion of the aneurysm treated with stent-assisted coiling.

In $72(75.79 \%)$ patients no new neurological pathological symptoms developed two to three days after endovascular procedure and they were discharged from the hospital (Fig. $1)$.

Intracranial complications of the procedure recorded in present study were a thromboembolic event or intracranial aneurysm rupture.

Intraprocedural complications occurred in four $(4.21 \%)$ cases: three $(3.16 \%)$ patients had a small thrombus on coil surface during the late phase of endovascular procedure and in one $(1.01 \%)$ case rupture of the aneurysm developed.

The status of the aneurysm (ruptured or unruptured) did not affect development of complications during the endovascular procedure.

Technical issues occurred in two $(2.1 \%)$ patients - in one non-detachment of coils and in the other $(1.01 \%)$ - coil dislocation. None of these technical issues was associated with clinical worsening.

Morbidity (mRs 1) was caused by SAH. In 19 (20.00\%) patients neurological symptoms remained even after the procedure. Six $(6.32 \%)$ patients had clinical worsening observed. In patients of both groups, SAH was diagnosed
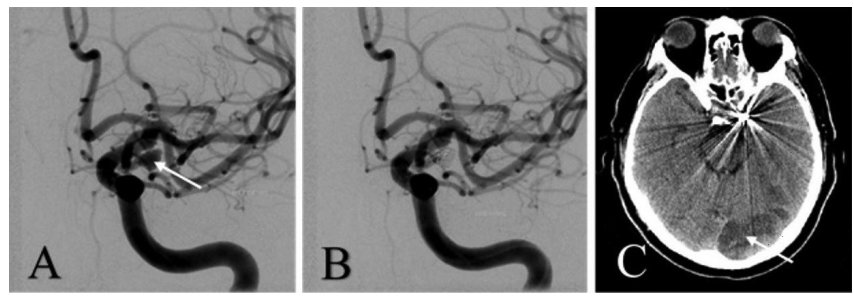

Fig. 2. Adverse clinical outcome (left posterior cerebral artery territory infarction) despite of technically completed occlusion of the aneurysm of the posterior communicating artery with Barricade coil system.

A, preprocedural digital subtraction angiography of the ruptured aneurysm (arrow). B, postprocedural digital subtraction angiography of complete occlusion of the aneurysm treated with coiling. C, non-contrast computed tomography showing hypodense region (arrow) associated with ischemia in the territory of left posterior cerebral artery.

Table 4. Comparative analysis of anatomical 6-month follow up post-procedural results in patients with ruptured and unruptured intracranial aneurysms using the simplified Raymond scale

\begin{tabular}{|l|c|c|c|}
\hline \multirow{2}{*}{} & \multicolumn{2}{|c|}{ Status of aneurysm } & \multirow{2}{*}{ Total } \\
\cline { 2 - 3 } & ruptured & unruptured & \\
\cline { 2 - 3 } & $26(44.07 \%)$ & $33(55.93 \%)$ & $59(100.00 \%)$ \\
\hline \multicolumn{2}{|c|}{ 6-month anatomical results } & $55(93.22 \%)$ \\
\hline Complete occlusion & $24(40.68 \%)$ & $31(52.54 \%)$ & $3(5.08 \%)$ \\
\hline $\begin{array}{l}\text { Residual neck of } \\
\text { the aneurysm }\end{array}$ & $2(3.39 \%)$ & $1(1.69 \%)$ & $1(1.69 \%)$ \\
\hline Residual aneurysm & $0(0.00 \%)$ & $1(1.69 \%)$ & \multicolumn{2}{|c}{} \\
\hline
\end{tabular}

Residual neck of the aneurysm - persistence of any portion of the original defect of the arterial wall but without opacification of the aneurysm sac. Residual aneurism - any opacification of the aneurysm sac

before endovascular manipulation. There was one $(1.01 \%)$ case of procedural related mortality (Fig. 2).

Six-month follow-up evaluation was performed for 58 $(61.0 \%)$ patients (59 IAs) after endovascular treatment with the Barricade coil system. Anatomical results of endovascular treatment of IAs were evaluated using radiological findings. MRA was performed in $34(58.62 \%)$ patients and DSA in $24(41.38 \%)$ patients. MRA was used in patients with coils only, since stents give MRA artefacts.

In the majority of patients complete occlusion of the aneurysm was detected and only in rare cases residual neck of the aneurysm or residual aneurysm remained (Table 4).

Six-month clinical results of endovascular treatment of intracranial aneurysms with the Barricade coil system were evaluated using mRs. In the majority of cases patients had favourable clinical outcome (mRs 0-2) six months after coiling procedure (Table 5).

The statistical analysis of the study resulted in the following main results.

Comparison of how the development of SAH influenced immediate anatomical outcomes - for all aneurisms together, according to Chi square and Fisher exact tests there was no significant difference $(p=0.586)$. For the same indicator for aneurisms at six-month follow-up, Chi squire and 
Table 5. Comparative analysis of clinical 6-month follow up post-procedural results patients with and without subarachnoid haemorrhage

\begin{tabular}{|r|c|c|c|}
\hline \multirow{2}{*}{} & \multicolumn{2}{|c|}{ Subarachnoid haemorrhage } & \multirow{2}{*}{ Total } \\
\cline { 2 - 3 } & SAH+ & SAH- & \\
\cline { 2 - 3 } & $25(43.10 \%)$ & $33(56.90 \%)$ & $58(100.00 \%)$ \\
\hline 6-month clinical results & \\
\hline mRs 0-2 & $22(37.93 \%)$ & $33(56.90 \%)$ & $55(94.83 \%)$ \\
\hline mRs 3-4 & $3(5.17 \%)$ & $0(0 . \%)$ & $3(5.17 \%)$ \\
\hline mRs 5-6 & $0(0 . \%)$ & $0(0 \%)$ & $0(0 \%)$ \\
\hline
\end{tabular}

$\mathrm{SAH}+$ patients with subarachnoid haemorrhage detected prior endovascular treatment.

SAH- patients without subarachnoid haemorrhage detected prior endovascular treatment. Modified Rankin scale (mRs): 0 - no symptoms; 1 - no significant disability; 2 - slight disability; 3 - moderate disability; 4 - moderate to severe disability; 5 - severe disability; 6 - dead.

Fisher exact test also showed no significant difference $(p=$ 0.311).

Comparison of how the development of SAH affected immediate clinical results for all patients together, the Chi squire and Fisher exact test showed a significant difference $(p=0)$. For this indicator in patients at six-month follow-up there was also a significant difference (Chi squire and Fisher exact test; $p=0.012$ ).

There was a significant difference in mRs, immediately and after six months (only in patients with six-month follow up) according to One-way repeated measures ANOVA ( $p=$ 0.026 ) indicating improvement over six months), and the same findings were showed by Friedman's ANOVA ( $p=$ $0.011)$ and the Wilcoxon Signed Ranks Test $(p=0.041)$.

There was no significant difference in anatomical results (three-step scale - Montreal) between immediate and six month results (only in patients with six-month follow up) according to One-way repeated measures ANOVA ( $p=$ 0.621 ) and the same findings were showed by Friedman's ANOVA $(p=0.655)$ and the Wilcoxon Signed Ranks Test $(p=0.655)$.

\section{DISCUSSION}

Coil embolisation in patients with unruptured IAs is associated with less mortality and morbidity, shorter hospitalisation time and less need for rehabilitation facilities after discharge from the hospital, compared to surgical clipping. In patients with ruptured IAs suitable for surgical clipping or endovascular treatment, embolisation is associated with improved independent survival in the first year and up to seven years compared to surgical treatment. In people who require treatment for IAs, but whom surgical clipping is too risky or not feasible, coil embolisation ensures survival benefits over surgical clipping (Anonymous, 2006).

EVT of IAs with bare platinum detachable coils was introduced in 1991 (Zidan et al., 2016). ISAT verified the clinical importance of EVT of ruptured aneurysms (Campi et al., 2007).
In 2016, Zidan et al. (2016) published a paper about IAs treated with the Barricade coil system, which demonstrated technical success of the procedure in all aneurysms, with technical issues in $5.7 \%$ of patients.

Technical success in our study was achieved in all of our patients, with technical issues only in $2.1 \%$ of patients. The high rate of success and low rate of technical complications reflected both the efficacy of the Barricade coil system and experience of our neuro-interventionists. Immediate anatomical results after our procedures were complete aneurysm occlusion in $90.72 \%$, residual neck of the aneurysm in $8.25 \%$ and residual aneurysm only in $1.03 \%$ of cases. Similar results were reported in a study on the Barricade coil system study in 2016, where these results were $81.4 \%$, $13.4 \%$ and $5.2 \%$, respectively.

The two most common complications of aneurysm coiling are thromboembolic complications and intraoperative rupture. In the ATENA study for unruptured aneurysms, the rate of thromboembolic complications and intraoperative rupture associated with endovascular coiling were reported to be $7.3 \%$ and $2.0 \%$, respectively (Pierot et al., 2008). In the Clarity GDC study for ruptured aneurysms, these rates were $13.3 \%$ and $3.7 \%$, respectively (Cognard et al., 2011). In our study the rates of thromboembolic complications and intraoperative rupture were $2.2 \%$ and $0 \%$, for unruptured aneurysms and $4.0 \%$ and $2.0 \%$ for ruptured aneurysms, respectively.

Typically, the first follow-up after EVT is scheduled three to six months after the procedure, then at twelve to 24month follow-up and a mid-term follow-up at three to five years. Most recurrences occur during the first year after the procedure (Lecler et al., 2015).

DSA with its high spatial resolution with $3 \mathrm{D}$ imaging and dynamic information allows scoring recurrent flow in the aneurysm. DSA is not impaired by device-related artefacts and remains accurate to visualise anatomical results of the endovascular procedure. However, DSA is an invasive procedure, which can lead to complications, such as cerebral thromboembolism, contrast nephrotoxicity or anaphylactic reaction, ionising radiation, and haematoma on the puncture site.

MRA is noninvasive imaging of choice with rare contraindications, such as ferromagnetic metallic implants and pacemakers. MRA can be performed as gadolinium contrastenhanced (CE) or as time-of-flight (TOF) MRA. Disadvantages of MRA include: lower sensitivity for slowly perfused aneurysm remnants, subacute thrombus may simulate an intrasaccular residual flow and TOF-MRA is more prone to motion artefacts.

For patients followed up with non-invasive imaging techniques (MRA), the appearance or evolution of a small residual neck will create a need to perform additional DSA to verify the diagnosis and to accurately evaluate the size of the remnant. In case of a good correlate, further monitoring may be performed noninvasively (Soize et al., 2016). 


\section{CONCLUSIONS}

1. Endovascular coil embolisation should take place in centres with expertise in both neurosurgery and endovascular neuro-interventions with adequate treatment to maintain good clinical outcomes.

2. Treatment of ruptured and unruptured intracranial aneurysms with the Barricade coil system is feasible, effective, and clinically safe and has a low risk of intraprocedural complications.

3. Further studies are needed to determine mid- and longterm durability results for the Barricade coil system.

\section{REFERENCES}

Anonymous (2006). Coil embolization for intracranial aneurysms: an evidence-based analysis. Ont. Health Technol. Assess. Ser., 6 (1), 1-114.

Benaissa, A., Barbe, C., Pierot, L. (2015). Analysis of recanalization after endovascular treatment of intracranial aneurysm (ARETA trial): Presentation of a prospective multicenter study. J. Neuroradiol., 42 (2), 80-85.

Broderick, J. P., Adeoye, O., Elm, J. (2017). The evolution of the Modified Rankin Scale and its use in future stroke trials. Stroke, 48 (7), 2007-2012.

Campi, A., Ramzi, N., Molyneux, A. J., Summers, P. E., Kerr, R. S., Sneade, M., Yarnold, J. A., Rischmiller, J., Byrne, J. V. (2007). Retreatment of ruptured cerebral aneurysms in patients randomized by coiling or clipping in the International Subarachnoid Aneurysm Trial (ISAT). Stroke, 38 (5), 1538-1544.

Cognard, C., Pierot, L., Anxionnat, R., Ricolf, F. Clarity Study Group. (2011). Results of embolization used as the first treatment choice in a consecutive nonselected population of ruptured aneurysms: Clinical results of the Clarity GDC study. Neurosurgery, 69 (4), 837-841; discussion 842.

Cognard, C., Weill, A., Castaings, L., Rey, A., Moret, J. (1998). Intracranial berry aneurysms: Angiographic and clinical results after endovascular treatment. Radiology, 206 (2), 499-510.

Grochowski, C., Litak, J., Kulesza, B., Szmygin, P., Ziemianek, D., Kamieniak, P., Szczepanek, D., Rola, R., Trojanowski, T. (2018). Size and location correlations with higher rupture risk of intracranial aneurysms. $J$. Clin. Neurosc., 48, 181-184.

Guerreiro-Simoes, R., Soize, S., Gawlitza, M., Manceau, P. F., Pierot, L. (2019). Intracranial aneurysms treatment with Barricade coils: Safety and 1 -year efficacy in a prospective, single-center series. J. Neuroradiol., 46 (5), 331-335
Lecler, A., Raymond, J., Rodriguez-Régent, C., Al Shareef, F., Trystram, D., Godon-Hardy, S., Ben Hassen, W., Meder, J. F., Oppenheim, C., Naggara, O. N. (2015). Intracranial aneurysms: Recurrences more than 10 years after endovascular treatment-a prospective cohort study, systematic review, and meta-analysis. Radiology, 277 (1), 173-180.

Mascitelli, J. R., Moyle, H., Oermann, E. K., Polykarpou, M. F., Patel, A. A., Doshi, A. H., Gologorsky, Y., Bederson, J. B., Patel, A. B. (2015). An update to the Raymond-Roy Occlusion Classification of intracranial aneurysms treated with coil embolization. J. Neurointerv. Surg., 7 (7), 496-502.

Molyneux, A., Kerr, R., Stratton, I., Sandercock, P., Clarke, M., Shrimpton, J., Holman R. International Subarachnoid Aneurysm Trial (ISAT) Collaborative Group. (2002). International Subarachnoid Aneurysm Trial (ISAT) of neurosurgical clipping versus endovascular coiling in 2143 patients with ruptured intracranial aneurysms: A randomised trial. Lancet, 360 (9342), 1267-1274.

Pierot, L., Spelle, L., Vitry, F. ATENA investigators. (2008). Immediate clinical outcome of patients harbouring unruptured intracranial aneurysms treated by endovascular approach: results of the ATENA trial. Stroke, 39 (9), 2497-2504.

Pierot, L., Wakhloo, A. K. (2013). Endovascular treatment of intracranial aneurysms: Current status. Stroke, 44 (7), 2046-2054.

Raaymakers, T. W., Rinkel, G. J., Limburg, M., Algra, A. (1998). Mortality and morbidity of surgery for unruptured intracranial aneurysms. Stroke, 29 (8), 1531-1538.

Santillan, A., Gobin, Y. P., Greenberg, E. D., Leng, L. Z., Riina, H. A., Stieg, P.E., Patsalides, A. (2012). Intraprocedural aneurysmal rupture during coil embolization of brain aneurysms: role of balloon-assisted coiling. AJNR Amer. J. Neuroradiol., 33 (10), 2017-2021.

Soize, S., Gawlitza, M., Raoult, H., Pierot, L. (2016). Imaging follow-up of intracranial aneurysms treated by endovascular means. Why, when, and how? Stroke, 47 (5), 1407-1412.

Wakhloo, A. K., Mandell, J., Gounis, M. J., Brooks, C., Linfante, I., Winer, J., Weaver, J. P. (2008). Stent-assisted reconstructive endovascular repair of cranial fusiform atherosclerotic and dissecting aneurysms: long-term clinical and angiographic follow-up. Stroke, 39 (12), 3288-3296.

Wiebers, D. O., Whisnant, J. P., Huston, J. 3rd, Meissner, I., Brown, R. D. Jr., Piepgras, D. G., Forbes, G. S., Thielen, K., Nichols, D., O'Fallon, W. M., Peacock, J., Jaeger, L., Kassell, N. F., Kongable-Beckman, G. L., Torner, J. C. International study of unruptured intracranial aneurysms investigators. (2003). Unruptured intracranial aneurysms: Natural history, clinical outcome, and risks of surgical and endovascular treatment. Lancet, 362 (9378), 103-110.

Zidan, M., Gawlitza, M., Metaxas, G., Foussier, C., Soize, S., Pierot, L. (2016). Endovascular treatment of intracranial aneurysms with Barricade coils: Feasibility, procedural safety, and immediate postoperative anatomical results. J. Neuroradiol., 43 (5), 353-357.

Received 27 March 2019

Accepted in the final form 24 January 2020

\section{RETROSPEKTĪVS PĒTİJUMS PAR VIENĀ ĀRSTNIECĪBAS IESTĀDĒ ENDOVASKULĀRI ĀRSTĒTO INTRAKRANIĀLO ANEIRISMU EMBOLIZĀCIJU, PIELIETOJOT BARRICADE SPIRĀL̨U SISTĒMU - TŪLĪTĒJIE UN SEŠU MĒNEŠU REZULTĀTI}

Intrakraniālas aneirismas (IA) biežāk atrod Vilīzija loka lielo artēriju zarošanās vietās 1 1-5\% populācijas kas vecāka par 50 gadiem. IA plīsums izraisa subarahnoidālu hemorāg̣iju (SAH), ko novēro 6-8 gadījumos uz 100000 iedzīvotāju, un tam raksturīga augsta mirstība (40-50\%). Neplīsušu IA ārstēšanas mērkis ir novērst aneirismas plīsumu, bet plīsušas IA gadījumā tās uzdevums ir nepiel̦aut atkārtotu SAH. Randomizēti multicentru pētījumi pierāda endovaskulārās terapijas lielāku efektivitāti, salīdzinot ar kirurğisku ārstēšanu plīsušas IA gadījumā. Pētījuma mērḳis bija novērtēt Barricade coil sistēmas efektivitāti intrakraniālu aneirismu ārstēšanā. Endovaskulārās platīna spirāles ir zināmas jau vairāk kā 25 gadus, un to pielietojums mūsdienās ir kḷuvis par galveno ārstěšanas metodi gan plīsušām, gan neplīsušām IA ar mirstību līdz 2\% gadījumu. Pētījums veikts Paula Stradiṇa Klīniskajā universitātes slimnīcā 20 mēnešus ilgā laika periodā, tajā iekḷauti 95 pacienti (97 IA), kuriem IA ārstētas endovaskulāri, pielietojot Barricade spirālu sistēmu. No tiem 31 (32,6\%) vīrietis un 64(67,4\%) sievietes, vidējā vecumā $56 \pm 15$ gadi. Mazākā grupa pacientu 22 (23,16\%) bija asimptomātiski, bet 73 (76,84\%) pacientiem diagnosticêti neiroloğiski simptomi, kas tieši saistîti ar aneirismas palielināšanos un SAH. $52(53,6 \%)$ IA no visām bija plīsušas jau pirms 
endovaskulārās procedūras, izraisot SAH, bet $24(25,26 \%)$ pacientiem diagnosticētas neplīsušas simptomātiskas IA. No visām IA 64 $(66,0 \%)$ embolizācijas procedūrā izmantotas tikai spirāles, 22(22,7\%) IA ārstētas ar spirālēm, papildus implantējot neirovaskulāro stentu, bet $11(11,3 \%)$ IA embolizētas, pielietojot remodelāciju ar balonu. Tūlītējais endovaskulārās terapijas anatomiskais rezultāts un embolizācijas tehniskais iznākums novērtēts, izmantojot vienkāršoto Raymond skalu. Vairumā gadījumu panākta aneirismas pilnīga oklūzija, bet aneirismas reziduāls kaklinš vai reziduāls aneirismas maiss novērots retāk. Tūlīiējie klīniskie rezultāti novērtēti, lietojot modificēto Rankin skalu (mRs). Vairumam pacientu bija labs klīniskais iznākums (mRs 0-2), bet 4 (4,21\%) slimnieki nomira 1-6 dienu laikā pēc procedūras no SAH radītām komplikācijām. 72 (75,79\%) pacientiem netika novēroti jauni patoloǵiski neiroloğiski simptomi 2-3 dienu laikā pēc procedūras, un viṇi tika izrakstīti no slimnīcas. Intraprocedurālas komplikācijas attīstījās $4(4,21 \%)$ gadījumu, bet tehniska rakstura sarežğíjumi 2 (2,1\%) pacientiem. 19 (20\%) slimniekiem saglabājās neiroloǵiskie simptomi arī pēc procedūras, 6 (6,32\%) pacientiem klīniskais stāvoklis pasliktinājās, un 1 pacients nomira procedūras laikā. Anatomisko un klīnisko rezultātu kontroli pēc sešiem mēnešiem veica $58(61,0 \%)$ pacientiem (59 IA). Vairumā gadījumu konstatēta pilnīga aneirismas oklūzija un labs klīniskais iznākums (mRs 0-2). Mūsu pieredze rāda, ka gan neplīsušu, gan rupturētu aneirismu ārstēšana ar Barricade spirālu sistēmu ir efektīva, klīniski droša, un tai ir zems intraprocedurālo komplikāciju risks. 